\title{
A conversation with Stuart Orkin
}

S

tuart Orkin's research has spanned the length and breadth of hematology. Orkin (Figure 1), from the Dana-Farber Cancer Institute, identified the genetic mutations responsible for thalassemia and chronic granulomatous disease and later identified GATA-1, the master transcriptional regulator of blood cell development. His work has challenged long-held dogmas and led to many therapeutic avenues for hematological disorders. Watch the full interview at www.jci.org/videos/cgms to find out whether he has an entrepreneurial streak and what, if anything, taking on administrative positions has taught him.

JCI: Where did you grow up?

Orkin: I grew up in New York City. When I was born, my parents lived on the west side, near the Museum of Natural History; I learned to ride my bike in the museum park. Then we moved out to the suburbs and, my parents being largely New Yorkers who didn't like the suburban life, moved back to the east side. I lived there until I went off to college.

I was a studious, mischievous child and heavily into baseball. Being a Yankees fan, now in Boston, has its pluses and minuses, but most recently minuses. My father was a urologist with a solo practice in Manhattan; he was really the quintessential doctor. Many of his patients became friends and family. In fact, many of the people I remember growing up with were his former patients.

JCI: Did your father's medical career kindle your interests?

Orkin: Perhaps my interest in science. I'm not sure I was that interested in medicine. I didn't see myself doing what he did. When I was in high school, I had a chemistry teacher who had just graduated from MIT, and he was enthusiastic and encouraging, and I saw that as a potential path. When I went to MIT, I thought I was probably going to do physics, but then I realized when I got there that of the 800 students of the class, probably 600 of them were better in physics than I was because that's the nature of the place. So I quickly looked around for other things.

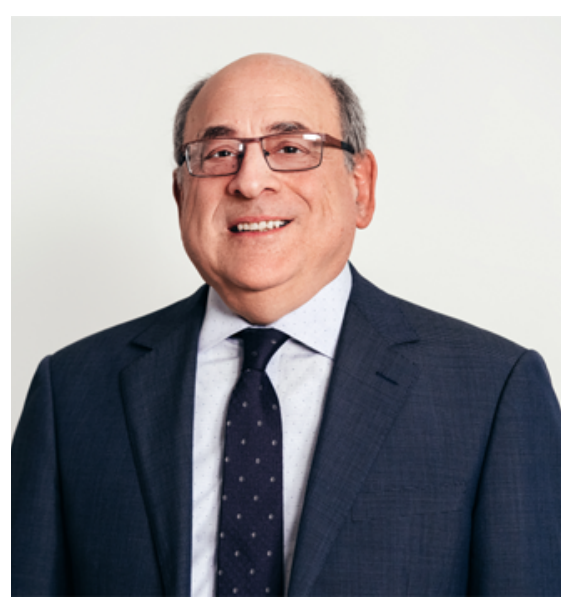

Figure 1. Stuart Orkin on February 24, 2017, in New York City. Image credit: Alexey Levchenko.

JCI: That other thing was pre-med?

Orkin: It wasn't really a pre-med school at that time. Now, a quarter of MIT students or more do biology and plan either to go to graduate school or medical school. When I went, the majors in biology were maybe a dozen out of the entire class. We were sort of the outcasts. During my second year, I took introductory biology, which was taught by [Nobel Prize winner] Salvador Luria. That was the burgeoning molecular biology era, and he was really great with the students and I figured it was something I ought to be doing.

JCI: When did you pivot towards medical school?

Orkin: When I was ready to graduate, I was trying to figure out which direction to take, and I wanted to combine science and medicine. Combined $\mathrm{MD}-\mathrm{PhD}$ programs were only in a couple of schools at that time, and when I looked around and applied to Harvard, they told me I could only get one degree. They said, "[Arthur] Kornberg had an MD from Harvard, has a Nobel Prize, and has chaired Biochemistry at Stanford. What do you need another degree for?" So if one degree was sufficient to do all that, I thought, okay.

JCI: But at that time, you still thought you would be primarily a scientist?
Orkin: I wasn't really that sure, but I had done quite a bit of research already. I worked summers in various laboratories. I spent one summer at the Rockefeller University, one summer at Albert Einstein Medical School. I had probably done about as much research as many $\mathrm{PhD}$ students by the time I graduated medical school.

JCI: Is that what led you to spend one of your years of medical school working with John Littlefield?

Orkin: Yes. In my medical school class, maybe six of us took a year's time on leave to do research. I chose John Littlefield because he did somatic cell genetics at that time and that was an interesting new topic. I spent a year with him and had the opportunity to be quite independent.

After that, I don't think I was entirely sure what sort of career I'd have, but it was the time of the Vietnam War and the tail end of the draft. I had the recommendation from a number of people to apply to the NIH, to the Public Health Service, which was really the primary training route for physicianscientists at that time. It was recommended that I consider Phil Leder as a mentor, and so I applied to the NIH program. The other advantage of that was that if you committed to go to the Public Health Service, they actually paid for your last year of medical school and you got a stipend as a fourth year student. The only downside of that commitment was that I had to go after one year of internship. And so I did an internship at Boston Children's Hospital, was at the NIH for two years, and then I had to decide at that point what direction to take.

JCI: At what point did you decide on pursuing pediatrics? And hematology?

Orkin: I think it came pretty early on. I decided that adult medicine was complex. Although as I get older, I like old people better, I wasn't sure that I liked old people at that point. I did like kids. I also saw it as an area where one could connect genetics to science much more easily. Then I thought hematology was, in many ways, the most organized science in terms of medicine; you could obtain the cells, you could do things with them, and it had many interesting diseases that one could pursue.

I came back to Boston as a resident 
because I wanted to complete pediatric training, and during the year of residency, I committed to a hematology fellowship, which would start the following year. About midway through that year, David Nathan called me and said that Bernie Forget, who recently, unfortunately, passed away, who was in the division at that time, had just accepted a position at Yale. David told me I would have his lab space, I would have his technician, I should obtain the application forms for grants from the NIH and the March of Dimes. I should just send these applications in, I would get my money, and I would begin my laboratory while I was a fellow. So I was sort of a fellow and junior faculty at the same time.

JCI: What were the first research topics you took on as you established your laboratory?

Orkin: If David hadn't come by with this offer, I'm not sure exactly what I would have done because the path would have been to enter someone else's lab, perhaps as a postdoctoral fellow. I wasn't sure what lab I would choose if faced with that, because when I came from the $\mathrm{NIH}$, we were doing what was, at that time, cutting edge molecular biology. I didn't think there were people locally who were much more advanced than I was at the time; maybe I was naive. But when David gave me the opportunity to be independent, I took up hemoglobin research because that's just something I had some experience with at the NIH with Phil Leder; there were also significant diseases, the thalassemias and sickle cell disease, about which one could begin to ask questions about genetics and gene expression.

Many people at that time probably thought I was not making the right decision because at that time, there were others in the field fairly well established. Bernie Forget was certainly established and had been recruited to Yale as a professor; Y.W. Kan, who's at UCSF, had been recruited from a division several years before and actually asked me while I was a fellow whether I wanted to join his group. And so starting out in that project area as one that I would concentrate in might, in retrospect, have been sort of foolhardy.

JCI: You were featured on the front page of the New York Times for coming up with the first prenatal diagnosis for thalassemias.

Orkin: That was an interesting time. That was in the summer of ' 78 , when I had just actually been formally appointed to the faculty. We had a family that was referred to Dr. Nathan that had a sort of unusual form of thalassemia where we knew there was a deletion in the globin genes. The family wanted prenatal diagnosis. David and his colleagues were doing diagnosis where one obtains fetal blood and examines globin chain expression.

Fetal blood drawing was risky, but there was a very good obstetrician who worked with David, and they were able to get me amniotic fluid cells so I could look at DNA and try to diagnose thalassemia through Southern blot analysis of fetal cells. And so we did that, the paper was published in the New England Journal of Medicine, and the remarkable thing was it actually appeared on the front page of the New York Times on the same day that Louise Brown, the first test tube baby, was born.

In the description of our work, the NYT referred to us as having "isolated a gene," which wasn't true at all, but it got miscommunicated in the lay press. So in addition to getting all this recognition and notoriety on the same day as Louise Brown, I actually got attacked in several news articles, including the Washington Post, where molecular biologists and other senior scientists accused us of grandstanding, claiming that we had isolated a gene. It was an awakening to the dangers of what can happen when you get your work described in the press.

JCI: You went on to use positional cloning to identify a gene for a disease, chronic granulomatous disease (CGD), without even knowing the underlying molecular basis.

Orkin: The thalassemia work wouldn't have gone as well if it weren't for partnership at the time with Haig Kazazian at Johns Hopkins. Haig is a geneticist who I knew from meetings, and he had a very well annotated cohort of patients, certainly much better than we had. When we had finished categorizing all the mutations in thalassemia, I was looking around for other disorders that genetics could be applied to.

It was at that time that we began to think about chronic granulomatous disease. There were a number of reasons for that: one is that, two floors down in the Ender's Research Building where I had my lab, was Lou Kunkel and his graduate student, Tony Monaco (who's now the president of Tufts University). They were working on the muscular dystrophy locus, which is relatively near the CGD locus. We had a chance to col- laborate with them, and just about the same time, Bob Baehner, who had been a former trainee in the hematology program, came on sabbatical for a year. He worked on linkage analysis and further locating the presumptive gene for CGD. We went on, with help from both Lou and Tony and a lot of luck, actually to clone the gene. That was a very exciting time.

JCI: This was then followed by other spectacular scientific discoveries like GATA-1, which specifies blood cell development, and more recently, you've been working on BCL11A, which governs the shift between fetal and adult hemoglobin.

Orkin: From GATA-1, the founding member of the blood transcription factors, we've learned basic principles that underlie both normal development and leukemias. BCL11A has attracted lots of interests from pharma, small biotech because increasingly, treatment of patients with hemoglobin disorders, particularly sickle cell disease, is seen as a global issue. I think now, because we understand some of the mechanisms and we have identified the proteins that are involved, they actually see established targets for the first time.

JCI: You have a known nose for talent and a spectacular reputation as a mentor. So what is your approach to mentoring?

Orkin: My approach is to be very accessible to the trainees. I like being totally straight and treating them as colleagues and not as subordinates. I try to give them enough freedom to be independent, but at the same time pay real attention to what they do. I've been fortunate because we've had extraordinary trainees come to the laboratory, and I never know how much of that is due to me, how much is due to what we do in the lab.

JCI: At the end of a particularly troublesome day, have you ever thought about a different career?

Orkin: Not seriously, but I think when I was growing up, I thought about law and architecture, but I have no three-dimensional sense, so the latter wouldn't have worked. Every once in a while I consider what else I might do, but I still think that the job I've had has been remarkably gratifying. It's really a privilege to do what we do because we enjoy most days and get paid for it. That's something most people don't have the privilege or luxury to do.

\section{Ushma S. Neill}

